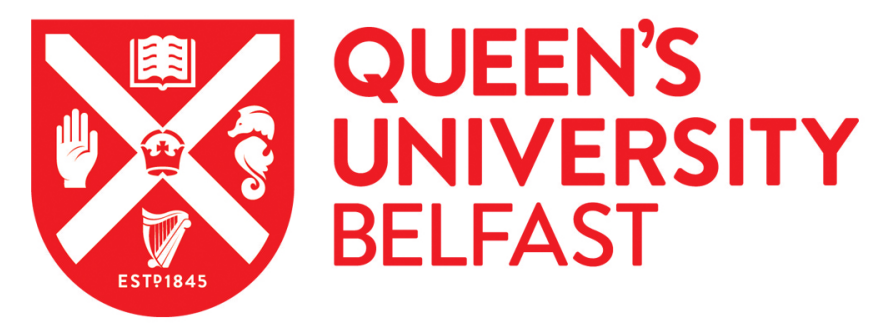

\title{
Accounting controls at the Society of Jesus - 1646 to 2005
}

Quinn, M., Oliveira, J., \& Santidrian, A. (2021). Accounting controls at the Society of Jesus - 1646 to 2005. Journal of Management History. https://doi.org/10.1108/JMH-10-2020-0066

Published in:

Journal of Management History

Document Version:

Peer reviewed version

Queen's University Belfast - Research Portal:

Link to publication record in Queen's University Belfast Research Portal

Publisher rights

Copyright 2021, Emerald Publishing Limited.

This work is made available online in accordance with the publisher's policies. Please refer to any applicable terms of use of the publisher.

\section{General rights}

Copyright for the publications made accessible via the Queen's University Belfast Research Portal is retained by the author(s) and / or other copyright owners and it is a condition of accessing these publications that users recognise and abide by the legal requirements associated with these rights.

Take down policy

The Research Portal is Queen's institutional repository that provides access to Queen's research output. Every effort has been made to ensure that content in the Research Portal does not infringe any person's rights, or applicable UK laws. If you discover content in the Research Portal that you believe breaches copyright or violates any law, please contact openaccess@qub.ac.uk. 


\section{Accounting controls at the Society of Jesus - 1646 to 2005}

\section{Abstract}

\section{Purpose}

This paper details the evolution of accounting controls conveyed as written rules at the Society of Jesus from the middle of the 17 th century to the present day.

\section{Design/Methodology/Approach}

An analytically structured history approach is adopted. Four "Instructions" are analysed in detail and institutional theory is used as a lens to examine influences on accounting control rules over time.

\section{Findings}

The analysis reveals that accounting control rules maintained a core stability over time but were adapted and extended according to internal and external factors. Changes to the rules were thus mostly evolutionary. Influenced by mainly external factors, over the years the rules have become more detailed and accompanied by more practical guidance.

\section{Originality/value}

This study provides an analysis of the evolution of accounting control rules at the Society of Jesus, which thus far has not been presented. It provides insights on how the rules introduced more clarity, and highlights the increasing recognition of secular management control and development with the Jesuit rules.

Keywords: Jesuits, accounting controls, financial management, rules, religious order.

Classification: Research Paper 


\section{Introduction}

The Society of Jesuits (hereafter Jesuits) dates from 1540, shortly preceding the CounterReformation period. According to O’Malley (2014), the Jesuits are Clerics Regular ${ }^{1}$, and devoted mainly to pastoral care. Building and managing schools was/is a key part of their work - by 1556 they had more than 30 schools. As noted by O'Malley $(2014,14)$ "schools ate up money [...], they were perpetually in debt and drove the Jesuits into [...] money raising" (see Alden, 1996, for more on college debt in France and Portugal). The first of the General Congregations (GC) the Jesuits' supreme governing body - took place in 1558 and one discussion item examined and approved the Constitutions - the spiritual foundations of the Society - which, as revealed later, clearly underpins Jesuits' approach to financial matters. Furthermore, matters of accounting and finance were regularly discussed at the $36 \mathrm{GC}$ up to and including $2016^{2}$. The Jesuits were supressed from 1773 to 1814 , but post suppression continued to expand in Europe, China, Africa and the United States. By 1945, they ran or were engaged with 4,500 schools with over one million students. From 1945 to 2000, the Jesuits continued to expand and as of 2019, there were about 16,000 Jesuits globally ${ }^{3}$.

Religious organisations have been studied by management history scholars (e.g., Bowden 2020; De Vaujany 2010; Keiser 1987; Miller 2006; Rost et al. 2010; Wirtz 2017) and accounting history scholars (e.g., a review by Cordery, 2015). As mentioned by De Vaujany, "numerous monks (and priests) participated in the design and diffusion of proto-managerial techniques, [...] in the field of accounting" (2010, 69), which can be attributed to a need to enhance the “economic efficiency" of religious organisations (Kieser 1987). A review of contributions on the theme of religion in the accounting literature by Cordery (2015) noted 90 articles over three decades, two prevalent themes being accountability and the sacred-secular divide. Cordery 
$(2015,23)$ noted many extant studies focused on micro perspectives (see later) of accounting, citing few studies detailing accounting control at the organisation-wide level. This is despite scholars such as Armstrong (1987), Burchell et al. (1980) and Walker (2016) emphasising the more macro role of accounting as a control in contemporary and historic contexts. In addition, studies in the management literature - e.g., Kieser (1987), Wirtz (2017) - while detailing rules about the governance of religious orders, have not explored formal/written accounting controls ${ }^{4}$ in detail. This scarcity of studies of accounting controls in the context of religious orders is a key impetus for this paper.

Developing our understanding of accounting controls in religious organisations, this paper analyses the evolution of formal and written accounting controls within the Jesuits, informed by an institutional approach, and follows an analytically structured history strategy (Rowlinson et al. 2014). Formal, organisation-wide texts ('Instructions') on financial and administrative matters are analysed through an institutional lens. These Instructions defined principles, goals, constraints, relations, controls and procedures over time and included detail on finance and accounting controls and related operational aspects of control. To date, these Instructions ${ }^{5}$ have not been the focus of detailed analysis from an accounting control perspective - although accounting and accountability in general within the Jesuits have been studied (e.g., Da Silva et al. 2017; Quattrone 2004, 2009, 2015). As formal rule-setting orientations and control mechanisms, they are part of the administrative control system (Malmi and Brown 2008) of an organisation, with the influence of religious principles embedded therein (see Kieser 1987). Therefore, cultural controls (Malmi and Brown 2008) also feature - directly, through self-control; and indirectly, through religiously-inspired formal controls. In this paper, we focus on the latter, 
the formal, administrative controls, based upon an analysis of five Instructions. In addition to providing a more detailed analysis of the Instructions, this study will assist researchers to distinguish clearly between accounting control practices in religious organisations prescribed at a global level (the emphasis here), practices diverging from them, or practices representing 'localisation' (Cruz et al. 2011). In addition, the analysis may be useful to researchers studying the sacred-secular divide, as organisation-wide rules may be useful to study not only whether and how this divide exists, but also how it may be influenced by external factors over time.

The paper is structured as follows. The next section provides a review of literature on accounting and religious organisations, as well as a summary of literature on institutional concepts drawn upon on for our theoretical framing of this paper. This is followed by the description of the research methods. Then, an overview of the accounting control rules adopted by Jesuits from the seventeenth century to the present day is given. The evolution of rules from the late nineteenth century is then discussed, drawing upon our theoretical framing. A concluding section summarises the paper and notes limitations and points for future research.

\section{Literature review}

Not-for-profits - including religious organisations - play/have played a vital role in society, often assisting the disadvantaged, marginalized or helpless. Over time, growth in the influence of notfor-profits, combined with highly publicised governance and fundraising issues, has led to increased sector visibility and public scrutiny (Hind 2017). In particular, the need for transparency and accountability has been widely noted (O’Dwyer \& Boomsma, 2015). However, to provide such accountability information externally (e.g., via publicly available financial 
statements), information must be first available internally (requiring accounting control systems and processes). Such information is integral to decision-making, planning and control (Hopper, Lassou, \& Soobaroyen, 2017). Thus, in the context of the present paper, secular society expects controls to be in place within the Jesuit organisation. How such control evolved over time is the focus here. We concentrate on a review of literature on religious organisations. Historical business literature on religious organisations remains relatively under-researched (Schwarz 2014; Spraakman and Quinn 2018). An overview of this literature is presented below to give a flavour of the type of research done, although not ambitioning to be an extensive review. This is followed by a brief overview of the concept of rules from an institutional theory perspective, which is used to frame the analysis later.

Studies with a religious focus have been published in accounting history journals. To begin, a 2006 special issue of Accounting History was dedicated to "Accounting and Religion". In this issue, Carmona and Ezzamel (2006) noted:

The lack of academic interest in studying accounting in religious institutions is rather perplexing, given the prominence of such institutions in most historical and contemporary societies, both spiritually and economically (Carmona and Ezzamel 2006, 117).

In this special issue, Cordery (2006) described accounting of a New Zealand mission order, suggesting early missionaries focused on sacred matters more than secular accounting and stewardship (see also Kieser, 1987), although letters of missionaries revealed accounts of expenditure and regular inventory lists. Espejo et al. (2006) recounted how Spanish brotherhoods did not comply with a census conducted by civil authorities in 1769 to establish their financial status: their responses were neither complete nor consistent. The enlightened Spanish State of this time was trying to reduce Church influence and in 1783 a law to regulate the brotherhoods 
was passed. Strangely, as Espejo et al. (2006) noted, it did not "prescribe any process of accountability" (2006, 144). Prieto et al. (2006) reported on accounting in a Spanish monastery, noting that although the accounting methods used were common at the time, "the specific characteristics of the sophisticated method used by the Benedictine monks served both accountability and decision-making purposes" (ibid, 242). Other studies include those of Dobie (2008a, 2008b) that detailed accounting at the Durham Cathedral Priory; Gatti and Poli (2014) detailing accounting and the Papal States; and Leardini and Rossi (2013) linking power and accounting in Verona's Santa Maria della Scala monastery.

There have also been studies in the general accounting and business literature. Kieser (1987, 119) observed that as monastic religious orders became more organised and introduced scientific methods (e.g., accounting), their "ascetic credibility" was reduced. Booth (1993) and Laughlin (1988) noted lack of research on accounting in churches/religious organisations and suggested an agenda be followed using "incomplete theorisations" (1993, 60) to build up comparative research. A common theme emerging from Booth (1993) and Laughlin (1988) was the sacredsecular divide - that accounting as a secular management practice may not align with religious values. This key theme of the sacred-secular divide is echoed in more contemporary works such as Jacobs (2005), Bigoni et al. (2013) and Baños Sánchez-Matamoros and Funnell (2015), although these papers suggested that accounting and spirituality are more aligned. Other contemporary studies linked and compared modern-day management practices to those of religious orders (e.g., De Vaujany, 2010; Hiebl and Feldbauer-Durstmüller 2014; Rost et al. 2010; Wirtz 2017). A key message from such literature is that something can be learned from organisations that have survived for centuries. The study by Hiebl and Feldbauer-Durstmüller 
(2014) compared the role of a cellarer in a Benedictine Abbey to a modern-day CFO role, focusing more on the systems and structures around accounting. Dobie (2015) also explored accounting, financial and management controls in early Benedictine monasteries, focusing specifically on statutes issued by Benedictine Chapters on financial and management controls. Finally, as a more general example, Mutch (2016) explored Scottish religious practices and how accountability therein resulted in a Scottish pre-eminence in early accounting textbooks in the mid to late 1700s. Thus, accountability is a second common key theme in the historic literature on accounting and management in religious organisations, in which the type and degree of accountability vary. This is not unexpected, given the timescales involved and differences between religious organisations. For example, it could be expected that monastic religious orders such as the Benedictines, Cistercians and Dominicans reflect more accountability to God in their rules and statutes than other religious organisations, as captured by, for example, Dobie (2015), Hiebl and Feldbauer-Durstmüller (2014), Kieser (1987) and Wirtz (2017).

There are also some Jesuit-specific studies. Quattrone (2004) provided an extensive and rich view of the Jesuit organisation, and while detailing some elements of accounting and accountability practices, focused on the influence of non-economic arguments on the development of practices, e.g., "an absolutist ideology of the Roman Catholic doctrine during the Counter-Reformation" (Quattrone 2004, 674). He did mention the Instructio pro administratione rerum temporalium collegiorum ac domorum probationis Societatis Iesu - one of the Instructions studied later - but did not discuss it in detail. This Instructio, according to Quattrone $(2004,665)$ : ruled the relationships among the Provincial, the Rectors of the various colleges and the Procurators of the colleges. These rules, in brief, concerned what today would be described as management control and auditing. 
Quattrone $(2009,88)$ explored a treatise "Trattato del modo di tenere il libro doppio domestico col suo essemplare, by the Jesuit Lodovico Flori”. By examining this and another early accounting treatise, he offered insights on how accounting spread, aided by visual presentation, praxis, communication medium and organisation. Quattrone (2015) extended his prior work into the realm of institutional $\operatorname{logics}^{6}$. He concluded that the logics of the Jesuit organisation was not "anchored permanently in a substantive logic" (ibid., 411) in that while there were centralised administrative procedures, these were flexible to local context. Da Silva et al. (2017) explored oral-aural accountability and management through the practice of the Account of Conscience, which remains part of Jesuit life. They noted the advantages of this account over a written account, and how it was used in decision-making. However, like Quattrone's studies mentioned above, Da Silva et al. (2017) similarly did not discuss the texts of rules examined in this study.

In summary, while the literature mentions written rules in religious orders (including the Jesuits), a detailed analysis of accounting control rules, in particular using a theoretical lens, is not common. As noted by multiple authors throughout recent decades (e.g., Armstrong, 1987; Burchell et al., 1980; Walker, 2016), an increasing emphasis on accounting controls has emerged over time. As shown by e.g., Kieser (1987), an emphasis on control also grew in religious organisations over time. An extensive debate on accounting controls is beyond the scope of this paper, but it is useful to clarify their meaning: they are accounting techniques and artefacts which provide information to the control process. Since we examine Instruction texts in detail (see below), accounting controls here may manifest as e.g., 1) written procedures/rules describing accounting techniques, the keeping of accounting records, the application of financial controls to 
transactions and audit-type procedures; or, 2) accounting documents such as periodic accounting statements, actual versus budget comparisons and reporting templates.

This paper adopts an analytical structured history approach (Rowlinson et al. 2014), and a conceptual framework is necessary. We draw upon institutional theory, specifically the concept of rules. Institutional approaches and concepts have been used to study accounting and accounting controls over time (e.g., Burns and Scapens, 2000; Hiebl et al., 2015; Quinn, 2014; Spraakmann, 2006) and in organisational history studies such as Alajoutsijärvi et al. (2012), Mutch (2006) and Ogata (2015). Scott (2014) plotted schools of institutional thought across two dimensions (pillars, levels of analysis) and identified privileged carriers of institutional features. The pillars are termed regulative, normative or cultural-cognitive; and the levels of analysis are the world system, society, the organisational field, the organisational population, and a particular organisation/organisational subsystem. The pillars and levels are not isolated, are porous, and often involve multiple carriers of institutional features, and these three characteristics are useful to craft an analytical framework (Scott, 2014). Carriers of institutional features include symbols, relational structures, activities and artefacts. Here, we draw primarily on the normative pillar which emphasises rules - how things should be done. Much management accounting research conceptualises rules as formally defined, typically in manuals or books - e.g., Burns and Scapens (2000), Lukka (2007), Quinn (2014) and van der Steen (2011) - and placing a professional duty on actors to follow them. The regulative pillar may also influence rules, imposing a legal rather than a moral obligation. Today, externally oriented (financial) accounting is highly regulated by laws and standards; however, internal accounting information (the topic here) is regulated by norms and values - e.g., by the accounting profession or the norms of the organisation - placing 
it under the normative pillar for analysis purposes. Interestingly, although studies noted earlier do mention various rules of religious orders, they have not been linked conceptually to rules as defined by institutional theory. We propose that the use of institutional theory - and the concept of rules - is appropriate to the study of accounting controls (or other phenomenon) of religious orders as various strands of institutional theory have been used in the accounting literature to explain change and/or stability of accounting - e.g., Burns and Scapens (2000), Quinn (2014). Here the notion of stability is likely as important as change, given the relative continuity of religious orders over time.

\section{Methodology}

The key sources for this study are archival documents and published works. For context, textbooks on various GC (mainly by Padberg and colleagues), Jesuit administration and history were acquired through library sources. Additionally, a Jesuit contact (in an accounting role) guided us toward further library and online sources, allowing us to acquire or access versions of the "Instruction on Temporal Administration" (ITA) - more recently (2005) termed "Instruction on the Administration of Goods" (IAG). These latter sources form the main data source ${ }^{7}$. There have been studies on, for example, the Rule of St. Benedict and the Dominicans from a corporate governance perspective (e.g., Rost et al. 2010, Hiebl and Feldbauer-Durstmüller 2014, Wirtz 2017), and Kieser (1987) noted the Cistercians as having uniform accounting for all monasteries. However, the Jesuits are distinctive in specifying a separate set of rules for administrative purposes, i.e., separate from their guiding spiritual rules. 
The ITA/IAG span from 1646 to present, consisting five volumes - 1646, 1894, 1935, 1979 and 2005. We had full access to all texts, but limited authorisation to cite from the 2005 text as it remained in active use at the time of this research. Although copies of the 2005 text are in the public domain, our initial agreement permitted a high-level analysis, which was sufficient for discussion in this paper. The 1646 text was sourced on Google Books, and the 1894, 1935 and 1979 texts sourced through libraries. The 2005 text was both purchased online and made available to us by a Jesuit. The 1646 and 1894 texts are written in Latin, the other three in English. For the two Latin texts, we used a combination of personal contacts in the clergy with knowledge of Latin (for the 1646 text) and Google Translate (for the 1894 text) to derive working copies in English. The initial translations were refined based on our accounting and limited Latin knowledge, in particular since the automated translation did not always capture the intended meaning. Any adaptations were sense checked by our clergy contacts to ensure retention of original meaning. Reference was also made to general texts on the Jesuits to capture terms used by the Order. The final translations used for analysis were reviewed by all authors and our clergy contacts to ensure clarity of meaning.

The analysis of the Instructions implied consideration of other Jesuit texts (e.g., summaries of the GC) and of broader changes in society over time. While the 1646 Instruction is commented on later, it is excluded from detailed analysis and discussion as the period from 1646 to 1894 is extensive and thus difficult to explore comparatively; by extension, and due to scarcity of sources, the period since the Jesuits' creation in 1540 until 1646 is only briefly discussed later. Therefore, a periodisation typical of an analytical structured history emerged during the analysis as three distinct time periods. The first period was from 1894, the year of the second Instruction, 
to 1934 , the year prior to the issue of the third Instruction. This was just after the 1929 Great Depression, a major economic event indirectly referred to as a reason to address existing rules (ITA 1935, p. iii). The second period is 1935 to 2004, capturing the 1935 and 1979 Instructions and finishing before an extensive update to the Instructions in 2005. The earlier decades of this period also correspond to the emergence of internal (cost) accounting as a separate profession (e.g., Armstrong 1987), implying accounting controls and associated roles began to be more formal and commonplace in organisations (e.g., Hiebl et al. 2015). The third period is from 2005 to 2020, capturing the 2005 Instruction, the most extensive of all, as well as early discussions on a future Instruction.

Drawing on the institutional concepts described earlier, the Instructions are considered rules the formal and documented ways things should be done. Formalisation and codification of procedures are a feature of much organised religion (e.g., Berman 2009; Kieser 2007; Rost et al. 2010) and thus rules are an appropriate concept for this study. The period of the Instructions analysed largely precedes any external accounting regulation of not-for-profit organisations, and thus the normative pillar is most relevant, with the regulative pillar potentially relevant in more recent times. The level of analysis is the organisation - the Jesuits. Organisational rules can change gradually, and rules may be affected by external forces such as "technological change, economic shocks, legislation, external consultants, new entrants into the organisation" (Oliveira and Quinn 2015, 517). Here, influences at the world system and society levels are considered (e.g., States as producers of legislation, economies, expectations of society in general) relative to the Instructions to determine what may have brought about change. Instructions over time were thus compared, within their broader societal, economic and technological contexts, to identify 
potential factors affecting the evolution of rules. It is worth noting various lower organisational levels within the Jesuits (e.g., Provinces, Houses, colleges) affected by organisational-wide rules. While influences for institutional change can come from within organisations, such as from lower organisational levels, these influences are not explored here. Given our research objective, how individual members or lower-level aspects may have shaped actual organisational practices and even organisational rules are beyond this study.

\section{The evolution of Jesuit accounting control rules}

To provide context, a brief outline of the 1646 Instruction and some insights from various GC up to GC24 in 1894 are first given. Then, the accounting control rules from the relevant Instructions are summarised and later discussed relative to institutional pillars, to explore what may have influenced change.

\section{The period until the 1894 Instruction: a brief overview}

From 1540 to 1646 , to our best knowledge, no Instructions existed. This is generally confirmed by summaries of the first seven GC from 1558 to 1616 - see Padberg et al. (1994). Several references were made to decrees on financial aspects of running Colleges, for example - GC2, 1563, Decree 8 noted colleges should be well financed; GC3, 1573, Decree 43 noted underfinanced Colleges should be sustained with alms or income; and GC6, 1608, Decree 46 ordered remedies be found to pay debts of some (unnamed) Colleges. Decree 60 of GC8 in 1646 required each Local Superior and each Procurator (a role akin to a modern-day finance officer - see Quattrone, 2004) to "render an account of the household finances and write down in his own handwriting how much he had received and how much he is turning over to his successor" (Padberg et al. 1994, 299). The decree also stated: 
Finally, an instruction should be drawn up on this matter [...] according to the decrees of this congregation (Padberg et al. 1994, 299)

This Instruction was published in $1646^{8}$ as the Instructio pro administratione rerum temporalium Collegiorum, ac domorum probationis Societatis Iesu (Instructions for the administration of temporal matters of Colleges and Houses of Probation of the Society of Jesus) $)^{9}$. and addressed some accounting control practices ${ }^{10}$. A key reason for the Instruction - conveyed through previous GC - was the indebtedness of Colleges. For example, GC8 Decree 15 stated penalties be imposed on colleges with excessive debt and Daurignac $(1865,400)$ referred to Seville, where a Jesuit "contracted loans and purchased merchandise, with which he freighted ships, but without the knowledge of the Fathers" to support a college, resulting in debt. O'Malley (2014) noted that war (e.g., Thirty Years' War 1618-48), plague and shifting political regimes may also have contributed to College debts. Alden (1996), with reference to Jesuit administration in Portugal, also hinted at a lack of commonality of the application of polices set via the various GC - another potential reason to develop a common Instruction. The Instruction consisted of 16 pages of written instructions (i.e., rules) for Provincials, Procurators and Rectors ${ }^{11}$ and provided a template for the accounts of the Province (see Figure 1). The instructions to the Provincials also noted that "what is said for the whole Province applies to individual Colleges", implying each College would prepare a statement as shown in Figure 1.

\section{[Figure 1 about here]}

As already stated, we exclude the 1646 Instruction and the period until before the 1894 Instruction (both only briefly sketched out above) from our detailed analysis. The 1646-1894 period saw a total of 25 GC - GC9 (1649) to GC23 (1883). An analysis of the various Decrees of these GC, per Padberg et al. (1994), reveals that issues around accounting and control did 
feature, as summarised in Table 1. The 1646 Instruction applied to the entire Jesuit Order regardless of location (as did all subsequent Instructions). It is interesting to note that some GC post 1646 reflected how rules were not being applied - see e.g., GC14, Decree 12 as per Table 1 - something which, as will be shown, was stated in subsequent GC over time.

\section{[Table 1 about here]}

\section{Rules from 1894 to 1934 - and the 1894 Instruction}

GC24 took place from September to December 1892. Luis Martín was elected General, and following Decree 22, he was entrusted to "undertake the preparation of an ordinance $[\ldots]$ on temporal administration, to help us avoid various risks and undesirable consequences" - the reasoning being "the very nature of temporal possessions which we use has notably changed" (Padberg et al. 1994, 487). The nature of changes was not noted, but in the almost 250 years since 1646, the business and economic environment had changed dramatically - the Industrial Revolution occurred, tax laws became common, company laws and inheritance laws were introduced, and paper money became the primary means of exchange. Table 1 suggests that the 1646 Instruction was gaining more regular attention in the GC during the 1800 s - only GC20 (held in 1820) made no reference to accounting control issues. In 1894, Martín published the Ordinatio der rerum temporalium administratione or Ordinance for Temporal Administration ${ }^{12}$. This second Instruction consisted of 31 pages, some related to accounting controls. This Instruction noted the changed economic system and circumstances, the indebtedness of Colleges and the need to comply with secular law (specifically inheritance law). The early paragraphs (69) referred to a missionary fund (arca missionis), a foundations/pious causes fund and a seminary fund (arca seminarii) $)^{13}$ and their administration. Paragraph 43 required the procurator 
to keep accurate books of account, identify sources of income and keep record of inventories and assets. Paragraph 45 noted an annual report of income and expenses should be sent to the General (but no report templates were given), while paragraph 46 added that the books be examined by the Superior and a Minister (an administrative assistant ${ }^{14}$ ) at the start of each month, and notes of any important items be taken. The 1894 Instruction also introduced several policies and procedures (see Malmi and Brown 2008) around accounting and finance, which are summarised in Table 2. While some of the items referred to in this 1894 Instruction had been mentioned in previous GC (see Table 1), suggesting some gradual developments over time, this Instruction emerges as top-down attempt to introduce updated standardised controls for the Order. An indication of this can be gleaned from Decree 22 of GC24, which noted the congregants "listed various points that could be treated in the ordinance. Hearing and approving their statements, the congregation entrusted the task of developing this ordinance to Our Very Reverend Father" (Padberg et al. 1994, 487).

\section{[Table 2 about here]}

\section{Rules from 1935 to 2005 - and the 1935 and the 1979 Instructions}

In 1935, the third Instruction for Temporal Administration (ITA) was published. The reasoning was "to give practical rules concerning the use and applications of the juridical definitions and prescriptions contained both in the 1894 Ordinance for Temporal Administration and in some recent additions of the Code of the Canon Law ${ }^{15 "}$ (Ledóchowski 1935, iii). The 1935 ITA consisted of 91 pages, and from the outset noted administration should be prudent, wise and actions of importance had to be written. On accounting records, the 1935 ITA provided several guidelines. First, it noted account books should be carefully kept, using a clear and uniform 
method. Second, it mentioned control, noting there should be different accounts for different Houses or funds - even if administered by the same person - and separate accounts in all Houses in which different bodies have ownership of goods. Third, it outlined accounting processes, definitions of common accounting terms, as well as a list of the account books required and a description of how these should be prepared and kept - see Table 3.

\section{[Table 3 about here]}

The 1935 ITA clearly defined hierarchical positions for preparing and examining the accounts. The Local Superior administered goods belonging to an individual House, under control of the Provincial, who administered the goods of the whole Province. The Provincial, in turn, had to render an account to the General (see below). The Local Superior carried out functions by instructing officials - the Minister and Procurator - while drawing on their advice. The Minister attended to daily purchases, lesser repairs and directed lower officials. The Procurator would oversee all temporal administration of the House, that the terms of budgets were fulfilled, and monies provided spent in accordance with budget. At the end of each month and year, statements of the affairs/financial situation of each House were to be prepared by the Procurator. It was noted it was desirable that these use the same ledger headings as those in the statements sent to the General in Rome - an effort at standardisation. Table 4 presents a summary of the main features of the monthly and annual statements, together with some comments drawn from the ITA.

\section{[Table 4 about here]}

The 1935 ITA suggested that the Provincial, with the assistance of the Revisor (an internal auditor), should audit the affairs of each House at year end. In particular, the Revisor had to: 1) examine the books of accounts; 2) get an accurate knowledge of investments, liabilities, revenues 
and expenses (see Table 8); and 3) examine whether affairs had been well administered and titles to properties obtained. The ITA also reminded the Provincial of the 1894 Ordinance words: "nothing is of greater help in domestic administration than that the books be examined, not in a perfunctory manner, but seriously and in detail" (paragraph 220, p. 90). Additionally, the 1935 ITA detailed annual accounts to be sent to the General: first, a status temporalis annuus Domus (annual temporal statement) was to be sent at the end of the visitation (audit) of a House together with the report of the Visitor; second, a status temporalis triennalis Domus (triennial temporal statement) was to be sent every third year along with other triennial documents.

The 1935 ITA also stated that each Province had to have two Arcae (Funds): an Arca Sumptuum Communium and an Arca Seminarii. Two other Arcae were noted as desirable/useful: an Arca Fundationum and an Arca Causarum Piarum (see Table 5). Comparing these funds with those indicated by the 1894 ITA, the purpose of the former Missionary Fund was now met by the Pious Causes fund and the previous Foundation/Pious Causes Fund was divided. Additionally, a new fund was created for common expenses. The Procurator was to render a written account on administration of the Arcae to the Provincial every six months. The Revisor was responsible for the audit of these funds at year-end and reported to the Provincial and his Consultors.

\section{[Table 5 about here]}

The 1935 ITA also set out rules on investment, which it defined as the "changing of money into a productive form" (paragraph 64, p.29). Any investments should be done prudently, safely, profitably and exclude an appearance of trading or speculation. Investment could take the form of immovable goods, movable goods and houses/buildings. Some advantages and disadvantages of investing in land were noted. On movable goods, it was noted that most money had to be 
invested in Government bonds (or similar), rather than shares, and should be diversified. The ITA insisted on the avoidance of trading or even the appearance of trading - e.g., buying bonds with the intention of selling them as value increases, and repetitive trades. Also, bonds should not be purchased if entities had any unlawful or questionable purposes. On investment in shares, preference or debenture shares were preferable and buying shares in newly formed or unquoted entities was to be avoided. The GC prior to the publication of the 1935 ITA, GC27 in 1922/23, approved collected decrees of all previous GC. While GC27 decrees did not mention investments, Decree 207, subsections 2 and 3 highlighted that "great diligence and fidelity" be used in the management of temporal goods and that officials make "no changes without permission or depart from received norms" (Padberg et al. 1994, 569). Subsection 4 noted that "superiors who are negligent or wasteful in the management of their houses should not be allowed to go unpunished" (Padberg et al. 1994, 569). Thus, while these investment rules seem to allow for some flexibility, following norms was paramount - a requirement likely more prominent given post First World War economic conditions and the Great Depression.

Despite the guidelines of the 1935 ITA, in 1938 GC28, Decree 26 noted how insufficient observance of the 1935 ITA was causing harm in many Provinces (Padberg et al. 1994, 604). Decree 26 insisted on the rendering of accounts by the Procurator in Houses, the audit of Province funds by a Revisor, that Local Superiors asked for permission when extraordinary expenses exceeded limits and suggested new Procurators should have specialised training. This mention of training is interestingly balanced against a reference in Decree 26 to Decree 207 of GC27 (see above) about the potential sanctioning of superiors. 
In 1979, the fourth ITA was published. In its preface, Father (General) Arrupe noted that "because today the economic conditions $[\ldots]$ have changed, to say nothing of the manner of doing business, it has seemed useful and indeed almost necessary to draw up a new Instruction". The 1979 ITA (221 pages) also considered reforms of structures of Temporal Administration from GC32 in 1974. These changes reflected a revision of the Jesuit Statutes on Poverty, which required "distinctions between the Jesuit religious community and the institutional works or apostolates served by that community, and with clear accountability and appropriate control of the separate finances of the two" (Padberg et al. 1994, 40-41). Thus, the 1979 Instruction introduced new rules and explained existing rules in greater detail - particularly on tasks to be carried out by those responsible for administration. Indeed, the 1979 Instruction started by listing the functions and tasks of Temporal Administration. The roles of the Principal, of the Local Superior and of subordinate officials such as Directors and Bursars (Administrators) were expressed. The 1979 ITA replaced the word "Procurator" with "Treasurer" and stated functions of Treasurers more clearly, highlighting the required expert knowledge and skills. This latter point stems from GC28, Decree 26, that Procurators (Treasurers) have specialised training. Indeed, the continual study of the science and technique of administration, law, finance and organisation for all the Jesuits involved in administration was encouraged (Paragraph 8).

Table 6 depicts the four Province Arcae as per the 1979 ITA. In comparison to 1935, Arca Seminarii no longer applied to care expenses for the aged/sick; a new Arca, Arca Praevisionis, met this specific goal. The Arca Fundationtionum was left unchanged and the Arca Operum Apostolicorum was similar to the Arca Causarum Piarum in 1935. Finally, the former Arca Sumptuum Communium was removed, although a separate fund to support common expenses of 
the Province was required. Unlike the 1935 Instruction, which only mentioned that the Procurator should provide the Provincial with estimated expenses of the Arca Seminarii for the coming year, paragraph 201.18 of the 1979 ITA added that he had to prepare budgets for the coming year, for the common expenses account and for all Arcae.

\section{[Table 6 about here]}

Accounting controls were a key element compared to previous versions. First, on accounting methods, Paragraphs 30-32 and 183 noted that a general template of accounting reports must be produced for each Province. These could be adapted in accordance with generally accepted accounting principles (GAAP) in the nation concerned and should meet all civil regulations. This, it was suggested, would lead to a desirable uniformity in accounting. In addition, the accounting methods should be easily intelligible and adapted to the circumstances of each Work, Community or Institute. For example, in small communities, it might be sufficient to produce an annual account of receipts and payments, of cash in hand and at bank, and of debtors and creditors. In larger communities, double-entry bookkeeping should be used for a more elaborate presentation of periodical accounts, with notes and supporting documents, so that the financial and economic position may be thoroughly understood. To support these methods, Appendix III of the 1979 ITA included a Latin-English glossary of accounting terms, as well as templates to present the financial statements. These templates were the first templates in any Instruction since 1646.

Second, the 1979 ITA did not explicitly name accounting books as in 1935 (see Table 4). However, it mentioned key records to be kept, such as the day-to-day accounting, records of securities, written cards for immovable goods items, inventories of movable goods, and a special book for mass stipends. Planning and budgeting systems and internal/external controls gained 
more prominence. Paragraphs 40-48 described budgets, their usefulness, periodic comparison between budget and actual figures, and tasks in budget preparation and approval. Paragraphs 49 and 55 highlighted the objective of internal control as being to protect Jesuit property, and to ensure that individuals remain honest and maintain confidentiality. To achieve this control objective, the 1979 ITA mentioned instruments for internal supervision, accounting areas open to risk, and preventive measures such as the rotation of personnel or auditing practices. On the preparation and presentation of financial statements, the duties of those engaged and the goals to be achieved were very similar to those described in 1935, although their description was more detailed.

Third, the 1979 ITA contained new detail of the Treasurer's tasks. All communities or apostolic institutes must send the Provincial annual balance sheets and other financial and statistical information. According to Paragraphs 235.1 and 235.2, the Province Treasurer was required to collect these reports, examine them and make appropriate comments. Additionally, Paragraph 235.3 specified documents, notes and explanations to be prepared by the Treasurer and to be sent by the Provincial to the Father General in Rome. These included an annual report - a balance sheet, statement of revenues, expenses (see Table 8) and changes in fund balance, statement of changes in the financial position - as well as statistical information for Houses, Works/Institutes and the Province. These reports had to be presented using standard forms.

The 1979 ITA provided more detailed controls to be executed by two Revisors, the Revisor Domorum (for communities and institutes) and the Revisor Arcarum (for the Province). Paragraphs 231, 232 and 239 explicitly mentioned that an examination of the accounts and 
financial position carried out by the Revisors had to include consideration of Civil Law. In addition, the Revisor Domorum was required to inspect buildings in need of repair and, if necessary, examine the management of investments. Paragraphs 51-52 also noted that if Civil Law required it, an independent external audit might be appropriate, although it is noted that "this will sometimes be less convenient" and that if internal supervision were effective, the external audit should be avoided to reduce costs.

On investment policy, the 1979 ITA also introduced new rules. First, Paragraph 88 limited the ownership of investments to higher organisational levels. Second, investments in real estate were permitted via shareholdings in Property Investment Companies that owned first class property, did not use properties for immoral purposes and paid satisfactory returns (Paragraph 99). Third, participation in an Investment Trust (mutual fund) or the formation of a mutual fund internal to the Society within a Province were noted as alternative ways of investing in securities that offered advantages (Paragraphs 102.5 and 103). On investing in shares, purchases to be avoided were shares in companies owned by relatives of Jesuits (Paragraph 107.3) and shares in companies located in jurisdictions with lax regulations (Paragraph 104.2 named specific countries). Fourth, the purchase of jewellery or works of art was to be avoided, as these goods did not meet requirements of marketability, safety and sound return, and might cause scandal (Paragraph 109). Finally, it insisted that only skilled Jesuits and laymen should manage investments, and stated that experts had to be trustworthy, have no conflict of interest and be properly remunerated (Paragraph 101).

\section{Rules from 2005 to present - the 2005 Instruction ${ }^{16}$}


In 2005, the fifth Instruction, the Instruction on the Administration of Goods (IAG), was published and remains in force at the time of writing. The 2005 IAG, with 252 pages $^{17}$, includes a Preface by the General, Peter-Hans Kolvenback, and the Statues on Religious Poverty in the Society of Jesus. In the preface, the General mentions the need expressed by Provincials in a 2000 meeting to "present a more coherent picture of the vow of poverty and deepen the way today's Society lives it" (p. x). Like previous Instructions, this update is justified by economic and technological changes, such as "globalization, the exponential growth of information, the appearance of the Euro, the speed with which information is made available, etc.” (p. x).

The 201 pages of the IAG itself start with an introduction (Chapter 1) clarifying its nature, objective, audience and the nature of norms and their discernment. It also distinguishs between actual instruction and explanation/advice. Chapter 2, on "Legal Aspects and the Basics of Financial Administration", discusses the role, importance and characteristics of financial management within the Jesuits and the general legal framework. It also introduces important concepts for financial administration, introducing basic control mechanisms for ordinary and extraordinary financial administration, administration limits (Cifra-Limite) and permissions applicable for each hierarchical level, as well as the definition of surplus and excess goods. It also indicates persons who administer goods, in hierarchical terms and co-workers - including laity - but notes that financial administration is the responsibility of all. The presented administrative structure is aligned with a typical structure portrayed in a management textbook, providing practical advice for planning, organisation, coordination, execution and control - with accounting principles and documents given particular salience. The potential necessity and convenience of using consultants and other types of aid is acknowledged. A final section 
expands on the necessity of mechanisms of control and auditing, identifying permanent and occasional internal controls. In sum, Chapter 2 shows an increased awareness of secular laws and ways of management - also captured in Table 7 below.

The three following chapters detail financial administration at the local, Province and General level. Chapter 3 (local level) notes the important distinction between Communities (or Houses) and Apostolic Works (or simply 'Works', or Institutions), which is relevant throughout the entire IAG. While the 1979 Instruction already noted this distinction, the IAG provided greater depth. Sections of Chapter 3 identifies persons responsible at the local level and their functions and authority. The descriptions of these functions provides relevant indications of the tasks assigned to each position, and relationships and reporting lines between those positions. An additional section expands and emphasises the importance of norms of internal control and even audits.

Chapter 4 (Province level) identifies assets administered by the Province - among others, the four funds (Arcae) as below-, people responsible and their functions and powers. Again, relations between these people are expanded when detailing activities of planning, organisation, coordination and financial reporting. The administrative division of the four funds (Arcae) remains as per the 1979 ITA. A Common (or Operating) fund also remains. However, additional funds are mentioned - the Trust and Agency Fund and Other Fund. Coordination with local Administrators and mutual technical and financial help between province Treasurers is also discussed. The chapter also discusses financial reporting by those working with the Provincial, by the Provincial and by independent auditors. 
Chapter 5 details financial administration at the General level. This is the first Instruction devoting a chapter to administration at this highest level. After briefly defining the powers and responsibilities at this level, it explores the functions and faculties of those involved - the General, the General Treasurer and his co-workers, the Revisor of General Financial Administration and the Finance Committee of the General. It also describes the objectives and operation of the Charitable and Apostolic Fund, or FACSI, controlled at this level.

Chapter 6 covers the main functions of financial administration, devoting particular attention to general concepts and procedures in the acquisition, administration and alienation of goods, leaving practical procedures to the following chapter. It starts by describing when incorporation of companies and other civil entities was required to represent the Society from a civil perspective. On the acquisition of goods, it distinguishes acquisition by income from persons (e.g., from work, mass stipends, pensions and other compensations), by productive activity or by accepting donations. Several rules regarding the important aspect of purchases are also included here.

Chapter 6 also devotes considerable attention to investments, specifying general indications on powers to invest and what to look for, and avoid, in an investment. It provides numerous, very specific instructions on different types of investments, distinguishing between investments in fixed assets/real estate and securities (movable assets). It also clarifies licit and ethical investments, prohibiting illicit investments. The chapter also mentions loans (both to persons outside and within the Society), renting of property, receiving deposits, employees (dependent or autonomous), co-workers and volunteers, and some notes on other work contracts and registered 
trademarks and copyright. The chapter also details the alienation of goods, providing general concepts on alienation in a strict sense (sale of property) and in a broad sense (creating limitations to the goods, such as rentals or mortgages), and closes with indications about judicial litigation and about buildings.

Chapter 7 elaborates on practical financial management procedures, providing detailed guidance and instructions about matters discussed in previous chapters. Budgets ar detailed first, stating who prepares them, and when, the approval process, on-going budgetary control, and what to do when expenses exceeded budget by $20 \%$. Chapter 8 provides forms - with explanatory notes - to be used in the multiple interactions and communications previously mentioned. After two initial forms for FACSI purposes, and two additional forms related to alienation of property/contracting debts, all other (eleven) forms are for reporting to Rome. Nine forms are for the Province level: statement of financial position, statement of activities, revenues, expenses and changes in net assets of the operating fund, year-to-year comparison of the financial position of the four permitted funds (Arcae) and of other funds, statistics and analysis (basic demographic and financial ratios) and a list of assets. The two final forms are for the financial reporting of Houses and Works to Rome, including both financial and non-financial variables and ratios. Comparing these forms with those of 1979, all have greater detail and are in English, not Latin. The chapter concludes with extremely detailed notes on how to complete the forms. Finally, chapter 9 contained an 8-page glossary of accounting and finance terms relevant to the Society. 


\section{Discussion}

The accounting control rules are now discussed drawing on the concept of rules to explore their evolution. It is worth noting that religious principles permeate all analysed texts - similar to other religious orders (e.g., Wirtz 2017). For example, the IAG (2005) was "done from an evangelical perspective" and the 1935 ITA noted "the close connexion between temporal and the twofold end ${ }^{18}$ of our Institute". This is not surprising for a religious organisation, and such values align to the normative pillar of institutions (Scott, 2014), with morals as a basis for legitimacy. However, these sacred values are not readily classifiable at an institutional level, yet they influence how the Jesuits function (organisation level), and how the organisation works internally (organisational sub-system level). These values are more aligned to the world system level of institutions as set out by Scott (2014). Such institutions possess much inertia and prevail for centuries (Williamson, 2000). These religious values also permeate lower institutional levels, such as the organisational sub-system of accounting controls, as institutional levels are porous (Scott, 2014). Instructions recurrently stressed that taking sound economic and financial decisions leading to efficient management of goods is key to support religious aims. Here, the regulative and normative pillars of institutions are relevant to offer explanations on how accounting control rules evolved in the various Instructions. As revealed above, the four analysed Instructions reveal a substantial increase in the importance attributed to accounting control issues over time. Table 7 visually captures this increasing importance based on key inclusions in the various Instructions ${ }^{19}$. Similarly, Table 8 reveals increasingly refined definitions of incomes and expenses over time (1894 -1979), which would have been reflected in the financial statements prepared. Table 8 also reflects a more specific desire over time to use accounting controls at all levels of the Jesuit organisation. While, as stated, we cannot directly refer to the 2005 Instruction, we can confirm 
the definitions/examples of incomes and expenses are similar to the 1979 one, with updates to reflect new types of expenses, such as expense on technology.

\section{[Table 7 about here]}

\section{[Table 8 about here]}

The introduction of rules (and the 1646 Instruction) was largely based on issues with running of colleges - see earlier. In contrast, the 1894 Instruction - our first for analytical purposes - noted how the industrialised world and society had changed considerably since 1646. For example, from about 1800 onwards, industrial firms adopted cost accounting approaches and calculated product profitability (Gervais and Quinn, 2016). Firms required more capital, company legislation eased attracting investors through limited liability and an accounting profession emerged (Zeff, 1971). This new world order brought changes in the economy and, as the Jesuits recognised (1894, ITA, section 1), in the temporal possessions they used; see also Table 1, where mention of accounting related issues was more common in the GC post 1800 . However, rules in the 1894 Instruction reflected internal issues at the organisational or organisational sub-unit level (Scott, 2014). New rules focused on roles and expectations of what should be done, and thus align with the normative pillar of institutions. Paragraphs 5 to 9 introduced various funds ${ }^{20}$ which stemmed from concerns from GC24, whereby provinces and missions might have their own fund "for ordinary expenses" (GC 24, Decree 17, Padberg et al. 1994, 484). This issue arose as Provinces were not permitted to have fixed incomes from their capital and some Provinces had used funds from Colleges and Houses for unintended purposes. The more internal focus of the 
1894 Instruction may also be reflective of the papal suppression of the Jesuits from 1773 to 1814 - the restored Society concentrating on re-building internally in the first instance.

The 1935 ITA was more practically oriented, providing details on how account books were to be kept (Tables 3 - 6). These additional and practical rules appear internally driven. The General made it clear in the preface to the 1935 ITA that instructions "in the manner of that former Instruction drawn up by Father Carafa with the authority of the $8^{\text {th }}$ General Congregation" be given. In an institutional framing, pressures to modify and/or expand the rules can be classified as stemming from the organisation (and possibly organisational sub-system) level, and the normative pillar - as standards, jobs and authority systems all feature. Some points are worthy of detail. First, the preface of the 1935 ITA noted rules were "desired in a special way concerning the investment of money" (p. iii), linking to the decrees of GC27 around proper management referred to earlier. Second, the general business environment became more bureaucratic and formalised in nature from the mid to late 1800s. For example, the accounting profession emerged from the late 1800s and given the greater level of practical accounting detail in the 1935 ITA, it is reasonable to postulate that the development of the profession influenced thinking on what practical accounting within the Jesuits should consist of. Another example is the increased presence of corporate legislation from the mid-1800s to address the increasing separation of firm management and ownership (see e.g., Foreman-Peck \& Hannah, 2012). Such influences represent the world system level (changing business environment), and the normative pillar (accounting profession values). Third, while there was a call for instructions in the manner of GC8, and while the 1935 ITA provided many details about keeping account books and suggested use of standard ledger headings in reporting, there was a lack of reporting templates (as in the 
1894 ITA). This is surprising given the context of poorer economic conditions (post the Great Depression) and increasingly professionalised accounting (by this time, an accounting profession was well-formed in most Anglo-Saxon countries) - although the 1894 templates likely still applied.

The 1979 ITA provided even more detailed guidelines and resumed to provide reporting templates. It also introduced clearer role definitions, budgets and accountability for separate components of the Jesuit organisation (Communities versus works/apostolates), akin to responsibility accounting. From an institutional framing perspective, several points are noteworthy. First, the 1979 ITA encouraged Administrators to comply with not only Jesuit statutes/ecclesiastical law, but also civil legislation - including on issues such as employment ${ }^{21}$, taxation and accounting (see also Table 7). This indicates no perceived ecclesiastical conflict in meeting requirements of civil law - even though, obviously, they defined different, specific requirements. While an example of a sacred-secular overlap, it is also an example of the regulative (civil law) and normative (religious values) institutional pillars. By 1979 accounting was also increasingly regulated, with accounting standards in issue in many countries (Camfferman and Zeff, 2007), and employment and taxation laws were commonplace - captured in Table 7 as depicted by the shaded items. Such regulative forces (accounting standards and business-relevant laws) stem from the world system level, leading to new rules in the 1979 ITA reflective of changes in how business was done, as suggested by Father Arrupe in the preface. Second, Table 6 reflects the arcae (funds) to be held at the Province level, and that annual budgets for the funds be prepared. These funds, and controls in general introduced by the 1979 ITA, are thus more internally driven - certainly, such controls and/or detailed accounting reports 
of religious organisations were not yet required by civil law. In terms of Scott (2014), the increased emphasis on (internal) accountability and control aligns with the normative pillar (internal expectations, rules, roles) and again the level of analysis is the organisation or organisational subsystem. Third, the updated 1979 rules on investment are reflective of the changed business world, representing an influence from the world system level upon the organisation level. In addition, they also reflect the norms of investing of the time, and thus reflect the normative pillar. It is worth noting that rules on investment also tightened from 1935 to 1979 , which also appears to be reflective of concerted efforts to standardise investment policies throughout the Jesuit organisation.

Finally, as noted earlier, the preface to the 2005 IAG clearly indicated that factors such as globalisation, greater information speed and availability, and the introduction of the Euro influenced the Jesuit organisation, and required a new Instruction. Such factors are reflective of the world system level as per Scott (2014) and affected all organisations to a greater or lesser extent during the period leading up to the 2005 Instruction. The General also noted in the preface that "these challenges have placed a demand on us to revise thoroughly the norms presently in force about temporal goods". Two key words from this quote are revise and thoroughly. In addition to greater depth and detail (see Table 7), the greatest distinction of the 2005 IAG lies in Chapter 8, which provided considerably more forms and templates than previous Instructions. While we cannot reveal detail (due to our confidentiality agreement), these forms and templates do portray a more formalised and standardised system of accounting and reporting. While this evolution may reflect changes in normative external accounting practices and the regulation of accounting in general in the period leading up to 2005, and other influences mentioned above, it 
may also reflect the desire for increasing internal formalisation within the Jesuits (i.e., the organisation or organisational subsystem). However, the 'thorough revision' announced in the preface should be framed in an awareness that the overarching approach and the major objectives, structures, organisation, processes, rules and roles remain generally similar. Therefore, the 2005 Instruction and each revised Instruction, are mostly an update to the extant context while keeping the same fundamental characteristics. This depicts an incremental, evolutionary change process (Johansson \& Siverbo, 2009), rather than any kind of revolutionary change - even when a 'thorough revision' is mentioned. Indeed, the 1979 ITA quite well captures the notion of continuity, with slow evolutionary change, when stating "continuity in administration" and "not depart from accepted practices" (p.23).

Reflecting on our research objective, what does the preceding discussion tell us about the evolution of accounting control rules as conveyed in the Instructions analysed? Overall, rules were updated according to the time and context in which they were written, and they depict an evolutionary change process. This change process gradually encapsulated secular accounting and management concepts - see also Table 7 and studies such as Jacobs (2005), Bigoni et al. (2013) and Baños Sánchez-Matamoros and Funnell (2015). This is in line with the institutional analysis of Scott (2014), which depicts upward (internal) and downward (external) influences on institutional levels. Assuming repeated enactment over time from 1894 - even considering that such enactment might have been sometimes imperfect, as recognised in some Instructions - these rules cannot but be considered as institutionalised (Burns and Scapens 2000). Thus, in contrast to some other religious orders who seemed to not have such detailed accounting rules, over time the Instructions created a "permanent institutional mechanism" (Dobie 2015, 145) of accounting 
control at the Jesuits. The Jesuits have persisted over time, despite being suppressed and subjected to various economic and social changes over time, and this persistence has been accompanied by institutional persistence (Ogata, 2015) of their accounting and control rules. However, the rules, while showing remarkable continuity, were adapted to capture business and societal changes over time (see Table 7) in an increasingly centralised fashion (not localised Cruz et al., 2011), and give practical guidance on their application.

Kieser $(1987,104)$ suggested that medieval monasteries became "the first bureaucratic iron cage [...] trading the chains of religion for the chains of bureaucracies". He also noted (but not in detail) the accounting abilities of the Cistercians - "their accounting system was much more advanced than that of the Benedictines" (ibid 118). Without getting into extensive detail, the content of e.g., the Rule of St Francis, the Rule of St. Benedict, the General Constitutions and Statutes of the Order of Friars Minor (Franciscans) and the Statute on Temporal Administration (Cistercians) is considerably less detailed compared to the Jesuit Instructions. For example, the Jesuit 2005 IAG of 201 pages contrasts to about five pages for the Cistercians 2002 Statutes - the most extensive of those non-Jesuits rules mentioned. The aforementioned religious orders all have statutes and constitutions setting out their religious values and ways of life, but it would seem the Jesuits have led the way in separating and formalising rules on accounting over time. The greater detail of Jesuits' rules also provides better support for its members to enact the intended practices to achieve fundamental objectives of the Order, such as living in poverty. They have, in the words of Oliver (1991), adopted an acquiescence strategy to institutional pressures as outlined above, i.e., they have complied with the normative and regulative demands of the times. This is not to say other religious orders have not complied with such pressures. The 
Jesuits have however made their compliance more visible through their written rules on accounting controls. They have also isolated to some extent their administrative rules from spiritual rules over time, developing a separate body of specific rules on financial matters - while embedding these within the broader objective of an ascetic life led in poverty, portraying the management of temporal goods (including in contexts of accumulation of wealth) as necessary to pursue religious goals, to paraphrase Kieser (1987). Thus, arguably, the Jesuits through their Instructions/accounting control rules have not traded religion for bureaucracy; instead, they have put each in two tightly connected 'iron cages', with the former functioning as a foundation for the latter. The bureaucratic controls have thus not invalidated controls enabled by the Account of Conscience as mentioned by Da Silva et al. (2017).

\section{Concluding comments}

This paper presented previously unexplored Jesuits' documents and analysed the evolution of four Instructions. The rules around the accounting controls defined therein were explored using an analytically structured history approach and an institutional lens framing. The analysis of the Instructions conveys stability and continuity over time, i.e., change has been evolutionary. It also conveys the Jesuits as an organisation adapting to meet evolving contexts and requirements around accounting control. It has also shown that the Jesuits have formalised accounting controls rules to a much greater extent than other orders. This formalisation of rules over time has, arguably, increased the legitimacy of the Jesuit organisation by producing texts (accounting control reports) which leave traces and signal the legitimacy of its activities (Phillips et al., 2004). 
This paper has some limitations. First, the paper is focused on Jesuits' written rules as defined in the four analysed organisation-wide Instructions and excludes both other documents (apart from brief references to, for example, Decrees from GC) and analysis of actual practice. While some literature (e.g., Alden, 1996; Dusausoit, 2012) has explored Jesuits' commercial activities and Quattrone (2004, 2009, 2014) and Da Silva et al. (2017) have explored accounting and accountability in a broader sense, more historical research on actual practices is relevant, as rules not enacted lose their relevance, fail to achieve their underlying objective and create organisational tensions associated with control failures. Having said this, the ongoing emphasis on complying with rules within the various Instructions over time is notable. Second, it should not be presumed that there is a 'causality' from rules to practices. However, as each revised edition of the Instructions contained reproductions of prior content, with more detail on required practice as opposed to major changes in practices being prescribed, it can be cautiously assumed that enactment of rules was at least satisfactory, despite Instructions themselves acknowledging some issues. Third, while we provide some tentative suggestions of factors which may have influenced these rules over time, further study is needed to support some of the explanations presented here.

While this paper has provided detailed insights on the various Instructions analysed, it also provides a broader basis for future research. Such research could include more work on detailed accounting practices within the Jesuits or other similar organizations. Such research will be aided by knowledge of Instructions as revealed here, as well as other publications referenced in the Instructions (e.g., Jesuit codes and Canon Law). Future work can use these texts as benchmarks to assess if rules of the Jesuits have been enacted in practice over time and explore why or why 
not - e.g., Alden (1996) and Quattrone (2004, 2009) suggest Jesuit accounting practices were/are

flexible but tend not directly contrast rules and practices. Another potentially interesting avenue

of future research is to explore if, and how, the increased formalisation of accounting and controls within the Jesuits assisted in the maintenance of the Order as an organisation i.e., its legitimacy. While not a key focus of this paper, legitimacy is of course a fundamental idea underpinning institutional theory (DiMaggio and Powell, 1991). Additionally, as detailed in the methods section, studying texts over a prolonged period and in multiple languages presented some difficulties. We hope the methods described here are useful to future researchers. Finally, the methods and theoretical lens used here could be useful to future research of other (nonreligious) not-for-profit organisations that may have had written rules over extended periods of time.

Notes

${ }^{1}$ See Vermeersch (1907).

${ }^{2}$ The $36^{\text {th }}$ GC in 2016 did not affect the documents analysed here, but requested a revision to the Instruction on the Administration of Goods (Decree 2,18).

${ }^{3}$ http://www.catholic-hierarchy.org/diocese/dqsj0.html\#stats, accessed 14 April 2021.

${ }^{4}$ Kieser (1987) provides some detail of the Rule of the Benedictines and Cistercians from a general management view. Little detail is provided on accounting related controls and rules.

${ }^{5}$ These Instructions have a broad affinity to the Rule of the Benedictines/Cistercians; however, their exclusive focus is temporal administration.

${ }^{6}$ Thornton and Ocasio $(1999,804)$ defined institutional logics as "the socially constructed, historical patterns of material practices, assumptions, values, beliefs, and rules by which individuals produce and reproduce their material subsistence, organize time and space, and provide meaning to their social reality".

7 The Instruction texts were generally commissioned by a GC, with the Father General tasked with their development. Who actually prepared/authored the texts is unclear.

${ }^{8}$ Our source of the original Latin text, http://books.google.ie/books?id=rY_hEo23msQC, indicates 1646, the year of Decree 60. However, the Instruction contains a sample report (see Figure 1) indicating the period "From 20 May 1647 until 30 Aug 1648", which may suggest a later publication date.

${ }^{9}$ This is our own translation. A house of probation is "a place for testing one's vocation" where the first two years of Jesuit formation occur (see http://www.jesuitica.be/assets/file/Schineller_JesuitGlossary.pdf ).

${ }^{10}$ Such internal books of instructions on accounting matters appear to have been quite uncommon at the time. One other example, but from a later period, is "Regulations and Instructions relating to His Majesty's Service at Sea established by His Majesty in Council", which dates from 1731 and included some accounting instructions (see McBride and Hines, 2018). Of course, several texts were available at that time in various languages on bookkeeping and accounting, e.g., Mellis (1543), Goessens (1594) and Flori (1636). The latter, Flori, was a Jesuit, and his text provides many examples of accounting using the double entry system. However, it does not appear to have had a major influence on the Jesuits' first Instruction. 
${ }^{11}$ A Province is typically a geographical area, led by the Provincial. A Rector is the director of a Jesuit community (a House where Jesuits reside). A useful outline of the hierarchical organisation of the Jesuits is given in Quattrone (2004).

12 "Temporal Administration" refers to the administration of material goods of a religious order or church.

${ }^{13}$ While Jesuits are bound by a Vow of Poverty, as stated in the Statues of the Society, their education and formation should be funded. The fund is elaborated for the first time in this Instruction, although it was mentioned in GC 23 (Table 1).

${ }^{14}$ See Peter Schineller's SJ Jesuit glossary available at https://studylib.net/doc/8560337/peter-schineller-s-jesuitglossary.

${ }^{15}$ This refers to a 1917 Code of Canon Law, the first official comprehensive codification of Latin Canon Law.

${ }^{16}$ GC36, held in 2016, requested the 2005 IAG and the underlying Statutes on Religious Poverty be revised. As of early 2020 , work was ongoing.

${ }^{17}$ There are 33 pages of "Statues on Religious Poverty in the Society of Jesus" within this number.

${ }^{18}$ These two ends refer to religious poverty and observance, both implying a temporal perspective.

${ }^{19}$ Table 7 is not extensive, but merely captures key items.

${ }^{20}$ According to Decree 33, GC23, an arca seminarii (seminary fund) was confirmed by an Ordinance of the Father General on March 19, 1859 (see also Table 1). This Ordinance is noted by O'Neill (2001) as an interim solution until rules could be added to prevent abuses of the fund.

${ }^{21}$ The 1979 ITA noted that the Society of Jesus must not only comply but even go beyond civil legislation in case it "fails to protect sufficiently the social rights of our employees" (Paragraph 79). 


\section{References}

Alajoutsijärvi, K., Kettunen, K., and Tikkanen, H (2012), "Institutional evolution of business schools in Finland 1909-2009”, Management \& Organizational History, Vol. 7, No.4, pp. 337-367.

Alden, D. (1996). The Making of an Empire: The Society of Jesus in Portugal, its Empire, and Beyond, 1540-1750. Stanford: Stanford University Press.

Armstrong, P. (1987), "The rise of accounting controls in British capitalist enterprises". Accounting, Organizations and Society, Vol. 12, No.5, pp. 415-436.

Baños Sánchez-Matamoros, J. and Funnell, W. (2015), "War or the business of God: Sacred mission, accounting and Spanish military hospitals in the 18th century" Accounting, Auditing \& Accountability Journal, Vol. 28, No. 3, pp. 434 - 459.

Berman, H. J. (2009) Law and Revolution: The Impact of the Protestant Reformations on the Western Legal Tradition. Boston: Harvard University Press.

Bigoni, M., Deidda Gagliardo, E., and Funnell, W. (2013), "Rethinking the sacred and secular divide: Accounting and accountability practices in the Diocese of Ferrara (1431-1457)", Accounting, Auditing \& Accountability Journal, Vol. 26, No. 4, pp. 567-594.

Booth, P. (1993), "Accounting in churches: a research framework and agenda", Accounting, Auditing \& Accountability Journal, Vol. 6, No. 4, pp. 37-67.

Bowden, B. (2020), "From Feudalism to Modernity, Part 2: The Revolution in Ideas, AD 450 to 1750 " in The Palgrave Handbook of Management History, London: Palgrave Macmillan.

Burchell, S., Clubb, C., Hopwood, A., Hughes, J., \& Nahapiet, J. (1980), "The roles of accounting in organizations and society", Accounting, Organizations and Society, Vol. 5, No. 1), pp. 5-27.

Burns, J. and Scapens, R.W. (2000), "Conceptualizing management accounting change: an institutional framework", Management Accounting Research, Vol. 11, No. 1, pp. 3-25.

Camfferman, K. and Zeff, S. A. (2007), Financial reporting and global capital markets: A history of the international accounting standards committee, 1973-2000. Oxford: Oxford University Press.

Carmona, S. and Ezzamel, M. (2006), “Accounting and religion: a historical perspective”, Accounting History, Vol. 11, No. 2, pp. 117-127.

Cordery, C. (2015), "Accounting history and religion: A review of studies and a research agenda", Accounting History, Vol. 20, No. 4, pp. 430-463.

Cordery, C. (2006), "Hallowed treasures: sacred, secular and the Wesleyan Methodists in New Zealand, 1819-1840”, Accounting History, Vol. 11, No. 2, pp. 199-220.

Cruz, I., Scapens, R. and Major, M. (2011), "The Localization of a Global Management Control System", Accounting, Organizations and Society, Vol. 36, No. 3, pp. 412-427.

Da Silva, J. B., Llewellyn, N., and Anderson-Gough, F. (2017), "Oral-aural accounting and the management of the Jesuit corpus. Accounting, Organizations and Society, Vol. 59, pp. 4457. 
Daurignac, J. M. S. (1865), History of the Society of Jesus: From Its Foundation to the Present Time (Vol. 1). Cincinnati: John P. Walsh.

De Vaujany, F. X. (2010), "A new perspective on the genealogy of collective action through the history of religious organizations", Management \& Organizational History, Vol. 5, No.1, pp. 65-78.

DiMaggio, P.J., and Powell, W.W. (1991). Introduction, in: Powell, W.W., DiMaggio, P.J. (Eds.), The New Institutionalism in Organizational Analysis. Chicago: The University of Chicago Press, pp. 1-40.

Dobie, A. (2008a), "The development of financial management and control in monastic houses and estates in England c. 1200-1540”, Accounting, Business \& Financial History, Vol. 18, No. 2, pp. 141-159.

Dobie, A. (2008b), “An analysis of the bursar's account at Durham Cathedral Priory, 12781398”, The Accounting Historians Journal, Vol. 35, No. 2, pp. 181-208.

Dobie, A. (2015), "The role of the general and provincial chapters in improving an enforcing accounting, financial and management controls in Benedictine monasteries in England 1215-1444", The British Accounting Review, Vol. 47, pp. 142-158.

Dusausoit, X. (2012), "Les jésuits et l'argent. Fondation et gestion de cinq collèges jésuites belges au XIXe siècle (Alost, Gand, Bruxelles, Mons et Verviers)", in Van Dijck, M., De Maeyer, J., Tyssens, J. and Koppen, J. (eds). The Economics of Providence. An Introduction to the Economic History of Religious Orders and Congregations, 1773-1930, pp. 247-266. Leuven: Leuven University Press.

Espejo, C. Á. D., Manjón, J. D. L., and Sánchez-Matamoros, J. B. (2006), “Accounting at the boundaries of the sacred: the regulation of the Spanish brotherhoods in the eighteenth century", Accounting History, Vol. 11, No. 2, pp. 129-150.

Flori, L. (1636), Trattato del modo di tenere il libro doppio domestico col suo esemplare. Palermo: Decio Cirillo.

Foreman-Peck, J., and Hannah, L. (2012), "Extreme divorce: the managerial revolution in UK companies before 1914”, The Economic History Review, Vol. 65, No. 4, pp. 1217-1238.

Gatti, M. and Poli, S. (2014), "Accounting and the Papal States: The influence of the Pro commissa Bull (1592) on the rise of an early modern state", Accounting History, Vol. 19. No. 4, pp. 475-506.

Gervais, P. and Quinn, M. (2016), "Costing in the early Industrial Revolution: Gradual change to cost calculation at US cloth mills in the 1820s". Accounting History Review, Vol. 26, No. 3, pp. 191-217.

Goessens, P. (1594), Buchhalten nach arth und weise der Italianer. Hamburg

Hiebl, M.R.W. and Feldbauer-Durstmüller, B. (2014), "What can the corporate world learn from the cellarer", Society and Business Review, Vol. 9, No. 1, pp. 51-73.

Hiebl M.R.W., Quinn, M., and Martínez-Franco, C. (2015), "An analysis of the role of a Chief Accountant at Guinness c. 1920-1940”, Accounting History Review, Vol. 25, No. 2, pp. $145-165$. 
Hind, A. (2017), "Fundraising in UK charities: stepping back from the abyss", Public Money \& Management, Vol. 37, No. 3, 205-210.

Hobsbawm, E. J. (1954), "The general crisis of the European economy in the 17th century", Past \& Present, Vol. 5, pp. 33-53.

Hopper, T., Lassou, P., and Soobaroyen, T. (2017), "Globalisation, accounting and developing countries", Critical Perspectives on Accounting, Vol. 43, pp. 125-148.

Jacobs, K. (2005), "The sacred and the secular: examining the role of accounting in the religious context”, Accounting, Auditing \& Accountability Journal, Vol. 18, No. 2, pp. 189-210.

Johansson, T. \& Siverbo, S. (2009), "Why is research on management accounting change not explicitly evolutionary? Taking the next step in the conceptualisation of management accounting change", Management Accounting Research, Vol. 20, No. 2, pp. 146-162.

Kieser, A. (1987), "From asceticism to administration of wealth: Medieval monasteries and the pitfalls of rationalization", Organization Studies, Vol. 8, No. 2, pp. 103-123.

Laughlin, R. C. (1988), "Accounting in its social context: an analysis of the accounting systems of the Church of England", Accounting, Auditing \& Accountability Journal, Vol. 1, No. 2, pp. 19-42.

Leardini, C. and Rossi, G. (2013), "Accounting and power in religious institutions: Verona's Santa Maria della Scala monastery in the Middle Ages", Accounting History, Vol. 18, No. 2, pp. 415-427.

Ledóchowski, V. (1935), An Instruction on Temporal Administration. The Manresa Press: London.

Lukka, K. (2007), "Management accounting change and stability: loosely coupled rules and routines in action", Management Accounting Research, Vol. 18, No. 1, pp. 76-101.

Malmi, T. and Brown, D. A. (2008), "Management control systems as a packageOpportunities, challenges and research directions." Management Accounting Research, Vol. 19, No. 4, pp. 287-300.

McBride, K. and Hines, T. (2018), "What shall we do with the drunken sailor? Accounting and controls for alcohol in the Royal Navy in the time of Nelson", in Accounting for Alcohol: An Accounting History of Brewing, Distilling and Viniculture, edited by M Quinn and J Oliveira, pp. 85-102, London: Routledge.

Mellis, J. (1543), A briefe instruction and maner to keepe bookes of accompts after the order of Debitor and Creditor, and as well for proper accompts partible etc. newely augmented and set forth by John Mellis, Scholemaister, London.

Merchant, K.A. and van der Stede, W.A. (2017), Management control systems: performance measurement, evaluation and incentives, $4^{\text {th }}$ ed, London: Pearson.

Miller, K. D. (2006), "A case for including religious organizations in management research", Journal of Management, Spirituality \& Religion, Vol. 3, No. 3, pp. 214-230. 
Mutch, A. (2016), "Religion and accounting texts in eighteenth century Scotland: Organizational practices and culture of accountability", Accounting, Auditing \& Accountability Journal, Vol. 29, No. 6, pp. 926-946.

Mutch, A. (2006), “The institutional shaping of management: In the tracks of English individualism". Management \& Organizational History, Vol. 1, No. 3, pp. 251-271.

O’Dwyer, B., and Boomsma, R. (2015), “The co-construction of NGO accountability: Aligning imposed and felt accountability in NGO-funder accountability relationships", Accounting, Auditing and Accountability Journal, Vol. 28, No. 1, pp. 36-68.

Ogata, K. (2015), “The Emperor is dead! Long live the Emperor!: a study of institutional persistence", Management \& Organizational History, Vol. 10, No. 1, pp. 21-38.

Oliveira, J., and Quinn, M. (2015), "Interactions of rules and routines: re-thinking rules", Journal of Accounting \& Organizational Change, Vol. 11, No.4, pp. 503-526.

O’Malley, J.W. (2014), The Jesuits: A History from Ignatius to the Present. Lanham: Rowman \& Littlefield.

O'Neill, C. E. (2001), Diccionario histórico de la compañía de Jesús, AA-Costa Rica (Vol. 1). Univ Pontifica Comillas.

Padberg, J.W. (1994), Together as a companionship. A history of the thirty-first, thirty-second and thirty-third General Congregations of the Society of Jesus. St. Louis: Institute of Jesuit Sources.

Padberg, J.W. (2009), Jesuit life and missions today: the decrees and accompanying documents of the 31st - 35th General Congregations of the Society of Jesus. St. Louis: Institute of Jesuit Sources.

Padberg, J.W. (1974), "The General Congregations of the Society of Jesus - a brief survey of their history", Studies in the Spirituality of the Jesuits, Vol. 6, No. 1-2, pp. 1-128.

Padberg, J.W., O'Keefe, M.D. and McCarthy, J.L. (1994), For matters of greater moments: The first thirty Jesuit General Congregations. A brief history and a translation of the decrees St. Louis: Institute of Jesuit Sources.

Phillips, N., Lawrence, T.B., \& Hardy, C. (2004), "Discourse and institutions", Academy of Management Review, Vol. 29, No. 4, pp. 635-652.

Prieto, B., Maté, L., and Tua, J. (2006), “The accounting records of the Monastery of Silos throughout the eighteenth century: the accumulation and management of its patrimony in the light of its accounts books", Accounting History, Vol. 11, No. 2, pp. 221-256.

Quattrone, P. (2015), “Governing Social Orders, Unfolding Rationality, and Jesuit Accounting practices: A Procedural Approach to Institutional Logics”, Administrative Science Quarterly, Vol. 6, No. 3, pp. 411-445.

Quattrone, P. (2009), "Books to be practiced: Memory, the power of the visual, and the success of accounting." Accounting, Organizations and Society, Vol. 34, No.1, pp. 85-118.

Quattrone, P. (2004), “Accounting for God: accounting and accountability practices in the Society of Jesus (Italy, XVI-XVII centuries)", Accounting, Organizations and Society, Vol. 29, No.7, pp. 647-683. 
Quinn, M. (2014), "Stability and change in management accounting over time - A century or so of evidence from Guinness", Management Accounting Research, Vol. 25, No. 1, pp. 76-92.

Rost, K., Inauen, E., Osterloh, M., and Frey, B. S. (2010), "The corporate governance of Benedictine abbeys: what can stock corporations learn from monasteries?”. Journal of Management History, Vol. 16, No. 1, pp. 90-115.

Rowlinson, M., Hassard, J. and Decker, S. (2014), "Research strategies for organizational history: a dialogue between historical theory and organization theory", Academy of Management Review, Vol. 39 No. 3, pp. 250-274.

Schwarz, C. (2015), "A review of management history from 2010-2014 utilizing a thematic analysis approach", Journal of Management History, Vol. 21 No. 4, pp. 494-504.

Scott, W.R. (2014), Institutions and Organizations: Ideas, Interests, and Identities (Volume 4) 4th Edition, Thousand Oaks: Sage.

Spraakman, G. (2006), "The impact of institutions on management accounting changes at the Hudson's Bay Company”, Journal of Accounting and Organizational Change, Vol. 2, No. 2, pp. 101-122.

Spraakman, G., and Quinn, M. (2018), "Accounting history research topics-An analysis of leading journals, 2006-2015”, Accounting Historians Journal, Vol. 45, No. 1, pp. 101-114.

Thornton, P. H., and W. Ocasio (1999), "Institutional logics and the historical contingency of power in organizations: Executive succession in the higher education publishing industry, 1958-1990”, American Journal of Sociology, Vol. 105, No. 3, pp. 801-843.

van der Steen, M. (2009), "Inertia and Management Accounting change", Accounting, Auditing and Accountability Journal, Vol. 22, No. 5, pp. 736-761.

Vermeersch, A. (1907), De religiosis institutis et personis, Bruges.

Walker, S. P. (2016), "Revisiting the roles of accounting in society". Accounting, Organizations and Society, Vol. 49, pp. 41-50.

Williamson, O.E. (2000), "The new institutional economics: taking stock, looking ahead". Journal of Economic Literature, Vol. 38, No. 3, pp. 595-613.

Wirtz, P. (2017), “Governance of old religious orders: Benedictines and Dominicans", Journal of Management History, Vol. 23, No. 3, pp. 259-277.

Zeff, S.A. (1971), Forging Accounting Principles in Five Countries: A History and an Analysis of Trends. Chicago, IL: Stripes Publishing Company. 